\title{
TESTING DIFFERENT LOYALTY TYPES IN A DESTINATION
}

\section{ISPITIVANJE RAZLIČITIH VRSTA LOJALNOSTI U JEDNOJ DESTINACIJI}

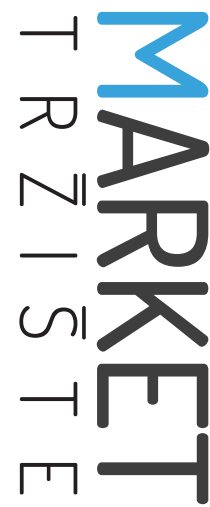

Market-Tržište

Vol. 32, No. 1, 2020, pp. 97-112

UDK 658.89:338.48-44(497.5)

DOI http://dx.doi.org/10.22598/mt/2020.32.1.97

Preliminary communication

\begin{abstract}
Marina Laškarin Ažića, Jasmina Dlačićc ${ }^{\text {, Vlado Galičićc }}$
a University of Rijeka, Faculty of Tourism and Hospitality Management Opatija, Primorska 42, 51410 Opatija, CROATIA, e-mail: marinal@fthm.hr

b University of Rijeka, Faculty of Economics and Business, Ivana Filipovića 4, 51000 Rijeka, CROATIA, e-mail: jasmina.dlacic@ efri.hr

c University of Rijeka, Faculty of Tourism and Hospitality Management Opatija, Primorska 42, 51410 Opatija, CROATIA, e-mail: vladog@fthm.hr
\end{abstract}

\begin{abstract}
Purpose - The purpose of this study is to explore three different loyalty types (loyalty to accommodation provider, destination loyalty, loyalty to the style of holiday) and how they are related to tourist satisfaction and experience motivation.

Design/methodology/approach - Data were collected in the Opatija Riviera, Croatia, using an on-site survey. In total, 169 useful questionnaires were subjected to further analysis. Since this study develops a new model, exploratory factor analysis (EFA) was performed first, followed by structural equation modeling (SEM) using the partial least square method.
\end{abstract}

Findings and implications - This study found that, among three loyalty types, overall satisfaction has the highest influence on loyalty to the style of holiday. Furthermore, this study revealed an important role of loyalty to the accommodation service provider in predicting destination loyalty.

Limitation - The study has several limitations: (1) the research was limited to only one destination over a relatively short period of time; (2) some potentially important controls, e.g. income, education and gender, were neglected; (3) the study provides an explanation of structural relationships without testing potentially important differences on the path level.

\section{Sažetak}

Svrha - Svrha je rada istražiti tri različite vrste lojalnosti (lojalnost pružatelju usluga smještaja, destinaciji i tipu odmora) te njihovu povezanost sa zadovoljstvom turista i motiviranošću doživljajem.

Metodološki pristup - Podatci su prikupljeni u sklopu terenskog istraživanja na Opatijskoj rivijeri, Hrvatska. Ukupno je prikupljeno 169 korisnih anketnih upitnika koji su se koristili za daljnju analizu. $S$ obzirom da se $u$ istraživanju predlaže novi model, prvo je provedena eksplorativna faktorska analiza (EFA), potom modeliranje strukturnih jednadžbi (SEM) metodom parcijalnih najmanjih kvadrata.

Rezultati i implikacije - Na temelju istraživanja dokazano je da ukupno zadovoljstvo ima najsnažniji utjecaj na lojalnost tipu odmora. Nadalje, otkrivena je važna uloga lojalnosti pružatelju usluga smještaja u predviđanju lojalnosti destinaciji.

Ograničenja - U radu se mogu istaknuti sljedeća ograničenja: (1) istraživanje je ograničeno na jednu destinaciju u relativno kratkom vremenskom razdoblju; (2) određene potencijalno važne kontrolne varijable nisu uključene u istraživanje, kao što su dohodak, obrazovanje i spol; (3) $u$ radu je provedeno strukturalno modeliranje bez testiranja različitosti razine hipotetskih veza. 
Originality - This study offers a new perspective of loyalty in the tourism and hospitality business, as these loyalty types have not been connected and tested together to date. It contributes to the existing findings of loyalty research in terms of new insights into tourism research methods, which were previously criticized as uninventive.

Keywords - loyalty to accommodation provider, destination loyalty, loyalty to the style of holiday, tourism experiences
Doprinos - Rad nudi novu perspektivu lojalnosti u turizmu i ugostiteljstvu uvažavajući da se radi o prvom istraživanju u kojem se povezuju i zajedno testiraju različite vrste lojalnosti. On doprinosi novim saznanjima o istraživačkim metodama na temu lojalnosti koje su se u prethodnim istraživanjima kritizirale kao ne inovativne.

KIjučne riječi - lojalnost pružatelju usluga smještaja, lojalnost destinaciji, lojalnost tipu odmora, turistički doživljaji 


\section{INTRODUCTION}

In the past two decades, loyalty has been seen as a central topic in destination marketing and management research, offering a heterogeneous picture of tourist loyalty drivers. However, when it comes to the hospitality business, researchers are unanimous: loyalty has been confirmed to be essential; it gives sense to future relationships between tourists and the hospitality company. Since the whole tourist system is mutually dependent, it is important to give feedback through a holistic view of loyalty, i.e. focusing on different loyalty dimensions.

Tourist loyalty represents the formulation of attitudinal modes of expression focusing on future intentions or current feelings towards a destination, brand (accommodation), style of holiday, or even festivals/events. From the perspective of accommodation providers, tourist loyalty represents one of the most enduring assets possessed by a company (Kandampully, Zhang \& Bilgihan, 2015), since key loyal guests contribute to revenue more than other guests do. The results deriving from long- term relationships between loyal guests and the company can be seen through a greater probability to buy products and services, generating higher profits, lower retention costs, etc. (McNaughton, Osborne, Morgan \& Kutwaroo, 2001). This implies that companies focus on keeping loyal tourists from a purely economic interest, which can be measured using indicators such as return on investment (ROI), guest lifetime value (GLV), etc. However, the same logic cannot be applied to destination loyalty because there are many different service providers in a destination, where benefits from loyal tourists are divided among all stakeholders. If we focus more thoroughly on loyalty, the specific style of holiday can also be considered. This adds to the complexity of loyalty types, as some tourists could be focusing on a particular way of spending their holiday that they want to experience, such as sailing, skiing, playing golf, etc. Therefore, if there is some preferred style of holiday, tourists may express greater loyalty to such style than to a destination or accommodation service provider.

If tourists do not feel attached to the accommodation provider or to a destination, they can be considered disloyal due to lack of awareness, product salience, or financial ability to afford the relationship (Tasci, 2017). An important limitation in such studies is non-awareness of other potentially important variables, such as loyalty to the style of holiday. Nowadays, as tourists are travelling more than ever, taking shorter vacations and visiting more than one destination during the holiday is becoming a growing trend (Rocco \& Andrew, 2011). Following these global trends, it can be assumed that tourist loyalty is not the exception in a changing world. Polygamous loyalty, multidimensional loyalty, vertical and horizontal loyalty, experiential loyalty (McKercher, Denizci-Guillet \& Ng, 2012) are present among consumers. In line with these recent findings, we presume that it is also important to test loyalty through different dimensions in order get a broader perspective of loyalty.

In research to date, cases where loyalty was measured with more than one factor, the difference between factors was mostly examined through different modes of loyalty expression (affective, behavioral, cognitive, conative, etc.), although the focus was on only one type (entity) of loyalty. In this study, loyalty is observed differently by assuming that tourists do not equally decide about their loyalty to a destination, accommodation provider, or style of holiday. Therefore, we enabled tourists to express loyalty by assessing different loyalty types simultaneously in a single destination.

The identified research gaps that directed our study are: (1) give a more holistic explanation of relationships between different loyalty types; (2) determine motivational background based on experiences that best predict three loyalty types; and (3) test effects of motivational background on three loyalty types, including the mediating role of satisfaction.

The paper is organized as follows: after the introduction, theoretical background and hypoth- 
eses are presented. This is followed by a description of the research methodology and findings. Finally, the results are discussed and a conclusion with managerial implications is offered.

\section{THEORETICAL BACKGROUND}

\subsection{Loyalty types in tourism research}

Despite an increased research interest in this topic, loyalty studies have been criticized for being uninventive, showing a lack of methodological and conceptual innovation (Almeida-Santana \& Moreno-Gil, 2018; McKercher \& Denizci Guillet, 2011). Loyalty in tourism and hospitality has mainly been tested through a unidimensional approach (one destination or one business), applying structural equation modelling to test causal relationships in the model. In those studies, attitudinal loyalty represents an endogenous factor containing highly interrelated variables, such as revisit intention, recommendation intention, attachment, price sensitivity, etc., while behavioral loyalty was used as a separate construct measured through the number of previous visits (Tasci, 2017). Some authors (Yuksel, Yuksel \& Bilim, 2010; Han, Kim \& Kim, 2011) have used loyalty phases, such as cognitive, affective, conative, and action, introduced by Oliver (1999), although seldom doing so in a fully contextualized manner to distinguish between different loyalty approaches. Compared to cognitive, affective, and action loyalty, Pedersen and Nysveen (2001) found that conative loyalty represents the strongest loyalty expression. Meanwhile, Suhartanto, Brien, Primiana, Wibisono \& Nyoman (2019) considered only conative loyalty, expressed as re-visit intention and intention to promote, as a good prediction of loyalty, especially in the service industry. Therefore, measures used to test different types of loyalty in this study are mostly focused on the conative approach.

Intention for a repeat visit and recommendation has been well-examined in previous re- search at the accommodation (Palacios-Florencio, García del Junco, Castellanos-Verdugo \& Rosa-Díaz 2018; Ben-Shaul \& Reichel, 2018) or destination level (Hallak, Assaker \& El-Haddad, 2017; Sato, Kim, Bunning \& Harda, 2018; Chung \& Chen, 2018), offering results that are applicable to this narrow interest. However, if the interests of tourists are neglected, research results may not fully illustrate their perceptions, nor can they provide answers as to how they see their loyalty in different contexts. This was also pointed out by McKercher and Denizci Guillet (2011), who warned that the failure to consider loyalty within a broader tourism context raises the prospect of producing misleading results. Therefore, in this study, a third level of loyalty is considered, which is mostly connected to tourists' specific needs, assuming that they may also be akin to a specific style of holiday. Tourists who take their selected type of holiday seriously return to the destination in order to experience the same emotion, and this is closely related with destination choice (McKercher et al., 2012). Loyalty to a specific way of spending one's holiday (experiential loyalty) is a relatively new type of loyalty, although this idea was put forward more than two decades ago by Stebbins (1996). According to the results of his research, someone who visits a place repeatedly either in search of broad understanding or visits different places in search of exemplars of his or her serious leisure activities, typifies the serious leisure participant. His study (based on volunteers) implicitly suggests that loyalty to a style of holiday relies deeply on personal reward, such as personal enrichment, self-expression and self-actualization, self-gratification, and self-image. Therefore, to accomplish such a reward, tourists may search for experience in either the same or in different destinations. Although the relevant role of all three types of loyalty (independently) has been pointed out in the literature, researchers have not tested the relationship between those types of loyalty simultaneously in one destination to date. Based on theoretical background, we propose the following hypotheses: 
$\mathrm{H}_{1}$ : Loyalty to accommodation provider positively affects destination loyalty.

$\mathrm{H}_{2}$ : Loyalty to the style of holiday positively affects destination loyalty.

\subsection{Antecedents of loyalty intention}

Satisfaction with services is considered to be among the most common variables used as a mediator in tourism loyalty models. The literature mainly points to the positive mediation effects of satisfaction on affective loyalty (Picon-Berjoyo, Ruiz-Moreno \& Castro, 2016), conative loyalty (Suhartanto et al., 2019), and conative loyalty and likelihood to recommend (Hallak et al., 2017). According to the expectation/disconfirmation paradigm proposed by Oliver (1980), in order to measure satisfaction, it is important to understand expectations before and after consuming products or experiencing a service. In line with his paradigm, tourist satisfaction occurs when post-purchase feelings about experiences (as a whole) match or exceed pre-purchase expectations. This is supported by Chen and Chen (2010), who argued that tourist satisfaction occurs if the expectations of tourist prior to travelling are fulfilled by the travel experience. Since satisfaction is closely connected to feelings, some authors evaluate satisfaction through both cognitive and emotional aspects of services, as well as with accumulated evaluation of various components and features (Antón, Camarero \& Laguna-García, 2017). According to Olsen and Johnson (2003), this "global satisfaction with services" or accumulated satisfaction is one of the most relevant factors in defining loyalty intentions. Following their work, satisfaction as a factor in this study includes the scales that evaluate satisfaction based on feelings and expectations from the entire experience.

Also, motivation as a driving force could affect tourist attitudes towards revisit and recommendation intention (Huang \& Hsu, 2009). Pearce (1982) was among the first authors to associate Maslow's hierarchy of needs to tourist motivation and behavior, arguing that tourists are pri- marily motivated by the possibility of achieving self-actualization, love and belonging, and fulfilling their physiological needs. Since travel is a way of enjoyment that enriches people's personal lives, experiences as drivers may also be an important factor that influences loyalty intention on three different levels. According to Tasci (2017), tourist loyalty to a destination may be an emotionally-driven construct described through the experiential view of consumption, which differs from the consumer perspective where products are in the center of consumption. Furthermore, Suhartanto et al. (2019) revealed that perceived value, tourist satisfaction, and motivation experience are antecedents with the strongest influence on loyalty intention. Compared to the recent study of said authors, this study aims to understand how motivation based on experiences influences three loyalty types.

The above observations led us to propose the following hypotheses related to three different types of loyalty:

$\mathrm{H}_{3}$ : Experience-based motivation has a direct and positive influence on overall satisfaction.

$\mathrm{H}_{4}$ : Overall satisfaction positively influences loyalty to accommodation provider.

$\mathrm{H}_{4 a}$ : Overall satisfaction mediates a positive relationship between experience-based motivation and loyalty to accommodation provider.

$\mathrm{H}_{5}$ : Overall satisfaction positively influences destination loyalty.

$\mathrm{H}_{5 \mathrm{a}}$ : Overall satisfaction mediates a positive relationship between experience-based motivation and destination loyalty.

$\mathrm{H}_{6}$ : Overall satisfaction positively influences loyalty to the style of holiday.

$\mathrm{H}_{6 a}$ : Overall satisfaction mediates a positive relationship between experience-based motivation and loyalty to the style of holiday.

\subsection{Age and previous visit}

Although previous research has shown that the relationship between motivation, satisfaction, 


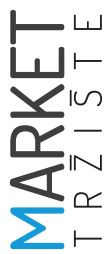

and loyalty is valid in the majority of contexts, it could also be assumed that other control variables are capable of altering these relationships. A number of studies point out that tourist characteristics are some of the common control variables used to test differences between exogenous (satisfaction, value, motivation, etc.) variables and future loyalty intention as an endogenous variable (Meleddu \& Paci, 2015; Wong \& Tang, 2016; Ganesh, Arnold \& Reynolds, 2000; Picon-Berjoyo et al., 2016). According to the results of previous research, demographic variables (e.g., age, gender, level of education) affect loyalty intention differently (Wong \& Tang, 2016). Hsu (2000) found that older customers (above 50 years of age) tended to show higher satisfaction and loyalty than the younger group (below 50 years of age). Similarly, Almeida-Santana and Moreno-Gil (2018) pointed to the connection between respondents' age and loyalty, where older respondents show a higher influence on destination and horizontal loyalty.

With regard to the number of visits to a destination or accommodation provider, previous research can be divided into two strands: (1) research that focuses on understanding the difference between habitudinal and real loyalty, and (2) research that tests the influence of the number of previous visits on attitudinal loyalty. The first strand of research, suggested by Riley, Niininem, Szivas, and Willis (2001), points out that the number of repeat visits in tourism should be viewed as a habit and not loyalty. In order to distinguish habitual users from loyalists, McKercher and Denizci Guillet (2011) explain that habitual users are driven by pragmatic reasons of convenience, location, safety, necessity, or laziness, without an emotional link with the service provider or destination, as opposed to real loy-
da-García, 2013; Kim \& Chalip, 2004). Compared to satisfaction, the number of previous visits has a less significant influence on the intention to revisit, implicating that overall satisfaction is the main determinant of attitudinal loyalty to a destination (Alegre \& Cladera, 2009). Following previous work, the control variables identified were expected to have a significant impact on three different loyalty types.

\section{METHOD}

\subsection{Research methodology and questionnaire design}

The present study focused on the Opatija Riviera (Croatia), a popular Croatian destination, where tourist overnights stays reached 1.2 million in first ten months in 2019. This destination was selected for its long tradition in tourism, dating from mid-19 ${ }^{\text {th }}$ century (Lončarić, 2015), and the continuous focus of local people and destination management on increasing both the overall experience and the number of loyal tourists. Tourists in Opatija as well as in Croatia mostly choose a destination for their vacation if it provides relaxing moments based on sun and sea during their vacation (Marušić et al., 2018). The age structure of a typical Croatian tourist in the peak tourist season, mid-June to mid-August, is represented by roughly the same numbers of Gen Y, Gen X and Baby boomers (CBS, 2020). Hence, tourists in Opatija could be used as proxies for those in Croatia who, beside age, also follow other characteristics identified among Croatian tourists (Blažević et al., 2017; Marušić et al., 2018).

Empirical research was conducted in order to find how tourists express their loyalty, while simultaneously comparing three different loyalty types using the same set of scales. Due to the specifics of tourism and hospitality business, the study was conducted on-site; paper-and-pencil questionnaires were prepared and administered through personal interviews. The research was conducted in Opatija during a period of four months, from June till September 2019, that is, during the tourist season in Croatia. Re- 
spondents who participated in the study were tourists older than 18, who stayed in the Opatija Riviera for more than one night. Out of 200 distributed questionnaires, 169 questionnaires (response rate of $84.5 \%$ ) were filled in and used as the sample for further analysis.

The questionnaire was developed in accordance with previous findings from the relevant literature. It consisted of four main parts: socio-demographic data, satisfaction, motivation, and loyalty intention, which was further divided into 3 groups and measured on a 7-point item Likert-type scale. Following Almeida-Santana and Moreno-Gil (2018), Jang and Feng (2007), 20 items were used to reveal motivations of tourists visiting the Opatija Riviera. With regard to satisfaction, a scale was adapted following Antón et al. (2017). For loyalty intention assessment we used the items adapted from the scales (Yoon, 2005; Vigolo, 2015; Folgado-Fernández, Hernández-Mogollón \& Duarte, 2017) that could be applied to all three loyalty types. Consequently, each type of loyalty was measured by the same set of items $(n=9)$, measuring word of mouth, conative, and cognitive loyalty. In order to ensure uniformity of all three versions of the questionnaire (German, English, Croatian), each version was translated and proofread by professional native speakers using the back-translation method (McGorry, 2000).

Descriptive analysis and exploratory factor analysis (EFA) were performed with IBM SPSS 21. The data was further analyzed using the partial least squares (PSL) technique and SMART PLS in order to estimate structural relationships. $\mathrm{PLS}$ is considered to be effective when there is a lack of empirical examination of the relationship among studied variables (Chin, 1998), and therefore it was the most suitable choice for our data analysis.

\subsection{Profile of respondents}

Out of 169 respondents, the majority were female (63\%) and 37\% were male. Respondents can be divided into 5 generational groups. The youngest group is Gen Z (from 18-22 years), accounting for $11.2 \%$ of respondents; the next group is Gen Y (from 23-36 years) with 25.4\% respondents; Gen X (from 37-52 years) accounted for $23.1 \%$ of respondents; the largest group consisted of Baby boomers (from 53-72 years) with 28.5\% of respondents; and lastly Traditionalists (from 73 years and older), accounting for $11.8 \%$ respondents. Among them, 43.2\% were employed, $7.7 \%$ unemployed, 32\% retired, while $17.2 \%$ were students. The respondents dominantly stayed in hotels (69.8\%), private accommodation (18.3\%), accommodation similar to hotels $(2.8 \%)$, camps $(1.8 \%)$, and other (7.1\%). Most of the respondents came from the European countries within $500 \mathrm{~km}$ of distance (48.5\%), 23.1\% were from the European countries that are more than $500 \mathrm{~km}$ away, $15.4 \%$ of the respondents came from another continent, and $13 \%$ were domestic tourists.

\subsection{Exploratory factor analysis, reliability and validity measurements}

Since this is the first study in which different loyalty types are simultaneously tested, first we applied EFA to reduce the large number of variables to a smaller and more meaningful number of factors that represent a subset of representative variables (Hair, Black, Babin \& Anderson, 2014). We used the maximum likelihood extraction method and Promax with Kaiser normalization rotation method. Bartlett's sphericity test showed significant results $\left(x^{2}=4415.403\right.$, $d f=465$, sig. $=0.000$ ), indicating that the constructs could undergo the next step (factor analysis). KMO value was 0.833 , showing good adequacy of the sample. Factor loadings ranged between 0.68 and 0.94 ( $p$-value <0.05), which is considered to be significant (Hair et al., 2014). Following the extraction of factors with strong interconnections, CFA was applied in order to test the measurement model (Table 1).

Table 1 shows acceptable and reliable measurement scales, as Cronbach's alpha ranges from 0.756 to 0.925 . Average variance extracted (AVE) was extracted for each factor and was greater

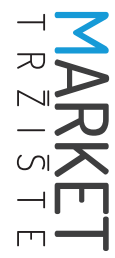


than the minimum criterion of 0.5 for all constructs, supporting good convergent validity. The study also satisfied discriminant validity re- quirements (Table 2), as the square root of AVE was greater than all corresponding inter-construct correlations (Fornell \& Larcker, 1981).

TABLE 1: Convergent validity and reliability of measurement scales

\begin{tabular}{|c|c|c|c|c|c|}
\hline Variable & Item & Loadings & $\begin{array}{c}\text { Cronbach's } \\
\text { alpha }\end{array}$ & CR & AVE \\
\hline \multirow{5}{*}{$\begin{array}{l}\text { Loyalty to } \\
\text { accommodation } \\
\text { provider - ACL }\end{array}$} & Intention to come back & 0.784 & \multirow{5}{*}{0.925} & \multirow{5}{*}{0.942} & \multirow{5}{*}{0.767} \\
\hline & First choice among others & 0.820 & & & \\
\hline & Interest to revisit within 3y & 0.933 & & & \\
\hline & Likelihood to revisit & 0.932 & & & \\
\hline & $\begin{array}{l}\text { Intention to stay again } \\
\text { during low season }\end{array}$ & 0.900 & & & \\
\hline \multirow{5}{*}{$\begin{array}{l}\text { Destination } \\
\text { loyalty - DESTL }\end{array}$} & $\begin{array}{l}\text { Intention to stay again in } \\
\text { the same destination }\end{array}$ & 0.815 & \multirow{5}{*}{0.926} & \multirow{5}{*}{0.944} & \multirow{5}{*}{0.773} \\
\hline & First choice among others & 0.867 & & & \\
\hline & Interest to revisit within $3 y$ & 0.941 & & & \\
\hline & Likelihood to revisit & 0.931 & & & \\
\hline & $\begin{array}{l}\text { Intention to stay again } \\
\text { during low season }\end{array}$ & 0.836 & & & \\
\hline \multirow{3}{*}{$\begin{array}{l}\text { Experience-based } \\
\text { motivation - } \\
\text { EMOT }\end{array}$} & Broaden horizons & 0.863 & \multirow{3}{*}{0.756} & \multirow{3}{*}{0.851} & \multirow{3}{*}{0.659} \\
\hline & $\begin{array}{l}\text { Variety of things to see } \\
\text { and do }\end{array}$ & 0.875 & & & \\
\hline & $\begin{array}{l}\text { Opportunity to see or } \\
\text { experience different ethnic } \\
\text { groups }\end{array}$ & 0.683 & & & \\
\hline \multirow{5}{*}{$\begin{array}{l}\text { Overall } \\
\text { satisfaction - } \\
\text { SATIS }\end{array}$} & Visit was satisfactory & 0.889 & \multirow{5}{*}{0.927} & \multirow{5}{*}{0.942} & \multirow{5}{*}{0.767} \\
\hline & Good decision to come & 0.898 & & & \\
\hline & Pleasant experience & 0.931 & & & \\
\hline & Quality tourist destination & 0.836 & & & \\
\hline & Worth revisiting & 0.843 & & & \\
\hline \multirow{5}{*}{$\begin{array}{l}\text { Loyalty to the } \\
\text { style of holiday } \\
\text { - LSH }\end{array}$} & $\begin{array}{l}\text { Intention to choose the } \\
\text { same style of holiday }\end{array}$ & 0.773 & \multirow{5}{*}{0.880} & \multirow{5}{*}{0.911} & \multirow{5}{*}{0.673} \\
\hline & First choice among others & 0.809 & & & \\
\hline & $\begin{array}{l}\text { Interest in revisit to have } \\
\text { the same style of holiday }\end{array}$ & 0.871 & & & \\
\hline & $\begin{array}{l}\text { Likelihood to choose the } \\
\text { same style of holiday } \\
\text { within 3y }\end{array}$ & 0.857 & & & \\
\hline & $\begin{array}{l}\text { Recommend the same } \\
\text { style of holiday }\end{array}$ & 0.788 & & & \\
\hline
\end{tabular}

Note: Variables with a factor loading lower that 0.6 were eliminated in order to achieve minimum threshold factor loading $(\lambda)=0.7$, as suggested by Nunnally (1978).

Source: Research results 
TABLE 2: Descriptive statistics and discriminant validity of factors

\begin{tabular}{|l|r|r|r|r|r|r|c|}
\hline & F1 & F2 & F3 & F4 & F5 & AGE & NRV \\
\hline Loyalty to accommodation provider & 0.876 & & & & & & \\
\hline Destination loyalty & 0.607 & 0.879 & & & & & \\
\hline Experience-based motivation & -0.073 & -0.019 & 0.812 & & & & \\
\hline Overall satisfaction & 0.188 & 0.284 & 0.253 & 0.880 & & & \\
\hline Loyalty to the style of holiday & 0.277 & 0.345 & 0.077 & 0.452 & 0.820 & & \\
\hline Age & 0.166 & 0.047 & -0.074 & 0.115 & 0.147 & 1.000 & \\
\hline Number of repeat visits & 0.277 & 0.312 & -0.160 & 0.057 & 0.147 & -0.057 & 1.000 \\
\hline
\end{tabular}

Note: Values on the diagonal are square roots of AVE. Other values below the diagonal represent correlation values.

Source: Research results

\subsection{Results of structural equation modelling}

To test the hypothesized causal effects of exogenous variables (overall satisfaction, experience-based motivation) on endogenous variables (loyalty to accommodation provider, destination loyalty, loyalty to the style of holiday), we applied the structural equation modelling (SEM) method. Results are presented in Table 3.

As shown in Table 3, there are three significant and positive relationships. However, hypothesis $\mathrm{H}_{3}$ could also be considered valid, but only tentatively, as suggested by Martínez González, Parra-Lopez, and Buhalis (2017) in their analysis of loyalty. More precisely, results show strong and significant positive effects: $\left(H_{1}\right)$ loyalty to accommodation provider and destination loyalty $(\beta=0.520$, $p$-value $<0.01) ;\left(H_{3}\right)$ experience-based motivation and overall satisfaction ( $\beta=0.253$, $p$-value < 0.01); $\left(H_{6}\right)$ overall satisfaction and loyalty to the style of holiday ( $\beta=0.433$, $p$-value $<0.1)$. With regard to unsupported hypotheses, two paths $\left(\mathrm{H}_{5^{\prime}} \mathrm{H}_{2}\right)$ showed a non-significant influence, indicating that satisfaction does not directly influence destination loyalty, and that loyalty to the style of holiday is not a predictor of destination loyalty ( $p>0.05$ ). Furthermore, in order to test predictive power of the model $\left(\mathrm{Q}^{2}\right)$, a blindfolding procedure was computed for endogenous variables (loyalty to accommodation provider, destination loyalty, loyalty to the style of holiday). The $Q^{2}$ values for loyalty to accommodation provider, destination loyalty, and loyalty to the style of holiday were higher than 0 (0.10; $0.31 ; 0.15$ respectively), indicating that the model has predictive relevance, as suggested by Hair, Hult, and Ringle (2017).

TABLE 3: Proposed hypothesis and significance

\begin{tabular}{|l|c|c|c|c|l|}
\hline HYPHOTESES & $\boldsymbol{B}$ & $\begin{array}{c}\text { Standard } \\
\text { deviation } \\
\text { (STDEV) }\end{array}$ & T statistics & P values & \\
\hline H1 ACL -> DESTL & 0.520 & 0.073 & 7.141 & $<0.01$ & supported \\
\hline H2 LSH -> DESTL & 0.134 & 0.085 & 1.572 & $>0.05$ & not supported \\
\hline H3 EMOT -> SATIS & 0.253 & 0.072 & 3.536 & $<0.01$ & supported \\
\hline H4 SATIS -> ACL & 0.153 & 0.065 & 2.359 & $<0.05$ & supported \\
\hline H5SATIS -> DESTL & 0.126 & 0.067 & 1.870 & $>0.05$ & not supported \\
\hline H6 SATIS -> LSH & 0.433 & 0.082 & 5.249 & $<0.01$ & supported \\
\hline
\end{tabular}

Note: satisfaction $\mathrm{R} 2=0.1$; loyalty to the style of holiday $\mathrm{R} 2=0.23$, loyalty to accommodation provider $\mathrm{R} 2=0.14$, destination loyalty R2 $=0.44$; path coefficient significant at the five percent level.

Source: Research results 
FIGURE 1: Summary of results - SEM

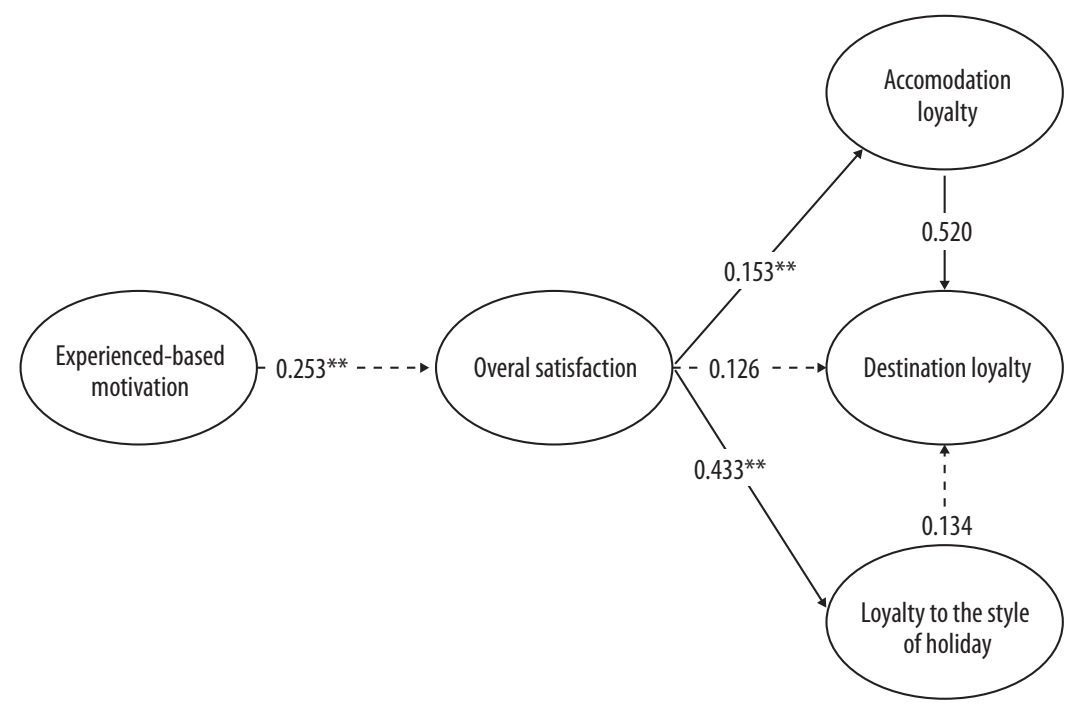

** Significant at $p<.01,{ }^{*}$ significant at $p<.05,---$ non-significant path

With regard to the mediation effects of satisfaction, following Hair et al. (2017), the results show that satisfaction fully mediates between experience-based motivation (EMOT) and loyalty to the style of holiday (LSH). For that relationship, the indirect effect was found to be significant $(p<0.05)$, while the direct effect of EMOT on LSH was not significant $(p<0.05)$. Specifically, experience-based motivation (through overall satisfaction) has the highest influence on loyalty to the style of holiday ( $\beta=0.110, p>0.05$ ) compared to other loyalty types (destination loyalty: $\beta=0.032$, p>0.05; loyalty to accommodation provider $\beta=0.039, p>0.05)$. Results are presented in Table 4.

TABLE 4: Mediation effects

\begin{tabular}{|c|c|c|c|c|}
\hline Direct effects & В & $\begin{array}{l}\text { T statistics } \\
\text { (|O/STDEV|) }\end{array}$ & $\begin{array}{c}\text { Significance } \\
\text { ( } p \text { value }<0.05)\end{array}$ & Hypotheses \\
\hline EMOT $\rightarrow$ ACL & -0.134 & 1.754 & No & \\
\hline EMOT $\rightarrow$ DESTL & -0.030 & 0.385 & No & \\
\hline EMOT $->$ LSH & -0.029 & 0.268 & No & \\
\hline \multicolumn{4}{|l|}{ Indirect effects } & \\
\hline H4a EMOT $\rightarrow$ SATIS $->$ ACL & 0.039 & 1.711 & No & not supported \\
\hline H5aEMOT $->$ SATIS $->$ DESTL & 0.032 & 1.505 & No & not supported \\
\hline H6a EMOT $\rightarrow>$ SATIS $\rightarrow>$ LSH & 0.110 & 2.447 & Yes & supported \\
\hline \multicolumn{4}{|l|}{ Total effects } & \\
\hline EMOT $\rightarrow$ ACL & 0.039 & 1.711 & No & \\
\hline EMOT $\rightarrow$ DESTL & 0.067 & 2.343 & Yes & \\
\hline EMOT $->$ LSH & 0.110 & 2.447 & Yes & \\
\hline
\end{tabular}

Source: Research results 
TABLE 5: Control variables

\begin{tabular}{|l|c|c|c|c|c|}
\hline CONTROLS & $\boldsymbol{B}$ & $\begin{array}{c}\text { Standard } \\
\text { deviation (STDEV) }\end{array}$ & $\begin{array}{c}\text { T statistics } \\
\text { (|O/STDEV|) }\end{array}$ & P values & VIF \\
\hline Age $>$ ACL & 0.164 & 0.074 & 2.230 & $0.026^{*}$ & 1.018 \\
\hline Age $->$ DESTL & -0.066 & 0.061 & 1.088 & 0.277 & 1.057 \\
\hline Age $>$ EL & 0.105 & 0.069 & 1.519 & 0.129 & 1.018 \\
\hline PV $\rightarrow$ ACL & 0.277 & 0.064 & 4.359 & $0.000^{*}$ & 1.007 \\
\hline PV $\rightarrow$ DESTL & 0.137 & 0.066 & 2.087 & $0.037^{*}$ & 1.105 \\
\hline PV $\rightarrow$ EL & 0.128 & 0.070 & 1.842 & 0.066 & 1.007 \\
\hline
\end{tabular}

Source: Research results

As shown in Table 4, there are two unsupported hypotheses ( $\mathrm{H} 4 \mathrm{a}$ and $\mathrm{H} 5 \mathrm{a}$ ), since overall satisfaction was not found to influence the positive relationship between experience-based motivation (EMOT) and destination loyalty (DESTL), or experience-based motivation (EMOT) and loyalty to accommodation provider (ACL). However, overall satisfaction mediates the positive relationship between experience-based motivation and loyalty to the style of holiday $(\mathrm{H} 6 \mathrm{a})$, implying that the relationship between experience-based motivation and loyalty to the style of holiday becomes stronger as overall satisfaction increases. In addition, although not explicitly hypothesized, the influence of control variables was also examined (Table 5), as suggested in the theoretical background.

The findings reported in Table 5 show a positive influence of age on loyalty to accommodation provider $(p<0.05)$. In other words, the older the tourist, the stronger their relationship to accommodation provider. Additionally, the number of previous visits significantly and positively influences loyalty to accommodation provider and destination loyalty. In addition to significant relationships, the results also indicate non-significant relationships, where age and the number of previous visits did not determine loyalty to the style of holiday. Specifically, the number of previous visits and age do not predict loyalty to the style of holiday. The multicollinearity test in Table 5 shows variance inflation factor values ranging between 1.007 and 1.057, which is below the acceptance level of 3 (Petter, Straub \& Rai, 2007).

\section{DISSCUSSION OF FINDINGS}

Numerous studies have tested antecedents of tourist loyalty through structural equation modelling, suggesting that destination and accommodation providers (hotels, motels, private accommodation, etc.) have a diverse structure of casual effects on loyalty intention. However, one destination or one business may not illustrate the whole perception of tourists of a specific destination if other dimensions are not observed at the same time. For example, tourists who are loyal to a destination do not necessarily need to be loyal to the accommodation provider, and vice versa. Therefore, this study proposed and tested a model of loyalty which includes three dimensions of loyalty, thus contributing to the development of measurement scales and existing literature on loyalty. Especially, with simultaneous testing of three identified dimensions of loyalty in one destination.

The study revealed a very complex structure between different levels of loyalty intentions. First, the results showed that loyalty to accommodation provider significantly influences only destination loyalty. This finding is partially in line with Kim, Choe, and Petrick (2018), who pointed out that festival brand loyalty affects attachment to festival destination. Although not in the same context, our results suggest that accommodation providers also represent an important piece of the whole (destination), where loyalty to accommodation provider affects destination loyalty (the higher the willingness to come or recom- 


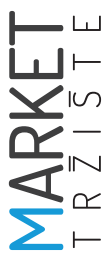

mend the accommodation service provider, the higher the willingness to come and recommend the destination). Furthermore, loyalty to accommodation provider does not affect loyalty to the style of holiday, since loyalty to the style of holiday reflects the hedonic dimension of loyalty. Therefore, tourists who express their loyalty intention to accommodation providers show a significantly higher connection to a destination. Second, the results show that experience-based motivation (EMOT) not only has a direct positive effect on tourists' overall satisfaction, but it also indirectly (through satisfaction) influences their future intentions with regard to their preferred style of holiday, i.e. experiential loyalty. This finding conforms to that of Kim (2018), who reported that memorable tourism experiences are the most influential determinant of future behavioral intention. Third, although overall satisfaction has a considerable direct impact on two loyalty types, results show that the strongest relationship is between satisfaction and loyalty to the style of holiday. This finding indicates that loyalty to the style of holiday is the strongest way of expressing loyalty among satisfied tourists. Tourists whose expectations regarding experiences were met show the highest interest in coming again and recommending their experiences regarding their preferred style of holiday to others. Fourth, age was found to not have an impact on destination loyalty or on loyalty to the style of holiday, which is corroborated by previous research (Mykletun, Crotts \& Mykletun, 2001). Similar results were reported by Chi (2011), who concluded that senior and younger travelers were homogeneous groups based on their perception of a destination, satisfaction judgment, and loyalty intentions. However, most studies consider age as a relevant demographic factor in predicting destination loyalty, or loyalty to several destinations simultaneously, suggesting that: "The greater the age, the greater the chances that an individual will be loyal to a destination" (Almeida-Santana \& Moreno-Gil, 2018, p. 250; Chen \& Gursoy, 2001). In contrast, the results in this study suggest that age is important in predicting loyalty to accommodation provid- er, compared to destination and loyalty to the style of holiday. Fifth, as expected and outlined by other authors (Yolal, Chi \& Pesämaa, 2017; Kozak, 2001), the number of previous visits is a significant predictor of destination loyalty and loyalty to accommodation provider. Specifically, first-time visitors tend to explore more locations within a destination, while repeat visitors tend to concentrate on fewer numbers of locations and have a greater likelihood for revisit intentions (Oppermann, 1996; Vigolo, 2015). Finally, when it comes to loyalty to the style of holiday, the number of previous visits was not found to be important in predicting loyalty to the style of holiday, contrary to findings of McKercher and others (2012).

\section{CONCLUSIONS AND MANAGERIAL IMPLICATIONS}

Concerning current trends in tourism that affect tourist behavior, it seems reasonable to expect that increasingly more complex behavioral patterns during the tourist visit make it more complicated to correctly measure tourist loyalty through intention to come or recommend in the future. Therefore, a unidimensional approach, as outlined in earlier studies (Almeida-Santana \& Moreno-Gil, 2018), does not seem to be the right measure to predict tourist loyalty. Our perception of tourist loyalty highlights the potential of developing more creative methodological alternatives, which will showcase this topic as the central research topic in the area of destination marketing and management.

Since this paper points out the importance of experiences as a key driver for coming to Croatia and for developing tourist loyalty, it is important to explore what kind of experiences stimulate their connection to destinations or people. Experience loyalty, as an alternative way of expressing loyalty, seems to be an important type of loyalty for those who seek experiences. The idea of loyalty to the style of holiday supports the concept of creative tourism, where destina- 
tions offer visitors the opportunity to develop their creative potential through active participation in courses, learning experiences which are characteristic of the holiday destination where they are undertaken (Richards \& Raymond 2000). Tourists who take their selected type of holiday seriously may also be determined as lovers of a specific way of spending their holiday, such as food lovers, photography lovers, dance lovers, etc. For those tourists, a unique experience, which they may be willing to recommend or experience again, represents the most valuable asset. Although this study reveals that loyalty to the style of holiday does not directly predict destination loyalty, a destination marketing organization (DMO) should think about creating memorable tourist experiences, since tourists who were motivated to come to a destination (based on experiences) show the strongest relationship to loyalty to the style of holiday.

If loyalty is approached as multidimensional, practitioners may not see a direct effect of such loyalty. Therefore, a DMO should highlight the importance of a symbiotic relationship for all businesses. Specifically, it is imperative for DMOs, as the organizations that manage a destination, to share the findings of recent research in order to improve cooperation between tourism and hospitality business. In such a scenario, a destination is able to compete with other destinations that understand the benefits of different types of loyalty. To attract and keep their tourists loyal, a DMO, as any other organization, should understand the motives for re(visiting) a destination and how their tourists express their satisfaction or loyalty.

\section{LIMITATIONS AND FURTHER RESEARCH}

Although this study brings new insights into loyalty research and reveals some important findings, several possible limitations need to be considered as it is a preliminary indicative study. First, our analysis was limited to only one destination in a relatively short period and in a specific time frame during peak season. It is recommended that further research includes at least two different time-periods, such as low season and peak season. Although loyalty studies (e.g., Almeida-Santana \& Moreno-Gil, 2018; Hallak et al., 2017; Wong \& Tang 2016) have focused on a single destination too, it would be intriguing to test the proposed model at two or more different tourist destinations. Furthermore, it is possible that destinations that focus on a specific type of tourism type, such as wellness, sport, or heritage tourism, etc., could have some specifics related to different loyalty types. Therefore, further research could address those and compare different destinations based on their dominant type of tourism. Second, certain control factors that were left out of this study, e.g., income, education, gender, should also be considered and could be included in future research. Third, this study provides an explanation of structural relationships without testing potentially important differences on the path level. Therefore, further research should also explore the differences between two groups of tourists using multigroup analysis, for example, differences between close and long-distance destinations, hotel vs. other types of accommodation, etc.

\section{Acknowledgment}

This research was financially supported by University of Rijeka, for the project ZP UNIRI 2/18. 


\section{References}

1. Alegre, J., \& Cladera, M. (2009). Analyzing the effect of satisfaction and previous visits on tourist intentions to return. European Journal of Marketing, 43(5/6), 670-685.

2. Almeida-Santana, A., \& Moreno-Gil, S. (2018). Understanding tourism loyalty: Horizontal vs. destination loyalty. Tourism Management, 65, 245-255.

3. Antón, C., Camarero, C., \& Laguna-García, M. (2017). Towards a new approach of destination loyalty drivers: satisfaction, visit intensity and tourist motivations. Current Issues in Tourism, 20(3), 238-260.

4. Ben-Shaul, M., \& Reichel, A. (2018). Motives, Modes of Participation, and Loyalty Intentions of Facebook Tourism Brand Page Consumers. Journal of Travel Research, 57(4), 453-471.

5. Blažević, B., Smolčić Jurdana, D., Peršić, M., Cerović, Z., Šimunić, M., Bašan, L., Jelušić, A., Krstinić Nižić, M., \& Rudan, E. (2017). Destinacijski akcijski plan Opatije 2016-2020 [Destination action plan of Opatija]. Avaliable at: http://www.opatija.hr/files/file/shared/2017/Destinacijsi-akcijski-plan-Opatije-2016-2020.pdf (Accessed April 28 ${ }^{\text {th }}, 2020$ ).

6. CBS (2020). Dolasci i noćenja turista u 2019 - Priopćenje. Zagreb: Croatian bureau of statistics.

7. Chen, C., \& Chen, F. (2010). Experience quality, perceived value, satisfaction, and behavioral intentions for heritage tourists. Tourism Management, 31(1), 29-35.

8. Chen, J., \& Gursoy, D. (2001). An investigation of tourists' destination loyalty and preferences. International Journal of Contemporary Hospitality Management, 13(2), 79-85.

9. Chi, C. (2011). Destination loyalty formation and travelers' demographic characteristics: A multiple group analysis approach. Journal of Hospitality and Tourism Research, 35(2), 191-212.

10. Chin, W. (1998). The partial least squares approach to structural equation modeling. In G. A. Marcoulides (ed.), Modern methods for business research (pp. 295-336). Mahwah: Lawrence Erlbaum Associates.

11. Chung, J., \& Chen, C. (2018). The impact of country and destination images on destination loyalty: a construal-level-theory perspective. Asia Pacific Journal of Tourism Research, 23(1), 56-67.

12. Folgado-Fernández, J., Hernández-Mogollón, J., \& Duarte, P. (2017). Destination image and loyalty development: the impact of tourists' food experiences at gastronomic events. Scandinavian Journal of Hospitality and Tourism, 17(1), 92-110.

13. Fornell, C., \& Larcker, D. F. (1981). Evaluating structural equation models with unobservable variables and measurement error. Journal of Marketing Research, 18(1), 39-50.

14. Ganesh, J., Arnold, M. J., \& Reynolds, K. E. (2000). Understanding the customer base of service providers: An examination of the differences between switchers and stayers. Journal of Marketing, 64(7), 65-87.

15. Hair, J., Black, W., Babin, B., \& Anderson, R. (2014). Multivariate Data Analysis. London: Pearson Education Limited.

16. Hair, J., Hult, T., \& Ringle, C. S. (2017). A Primer on Partial Least Squares Structural Equation Modeling (PLS-SEM). Los Angeles, CA: SAGE Publications.

17. Hallak, R., Assaker, G., \& El-Haddad, R. (2017). Re-examining the relationships among perceived quality, value, satisfaction, and destination loyalty: a higher-order structural model. Journal of vacation marketing, 24(2) 1-18.

18. Han, H., Kim, Y., \& Kim, E. (2011). Cognitive, affective, conative, and action loyalty: testing the impact of inertia. International Journal of Hospitality Management, 30(4), 1008-1019.

19. Hsu, C. H. (2000). Determinants of mature travels' motor-coach tour satisfaction and brand loyalty. Journal of Hospitality \& Tourism Research, 24, 223-238.

20. Huang, S., \& Hsu, C. (2009). Effects of Travel Motivation, Past Experience, Perceived Constraint, and Attitude on Revisit Intention. Journal of Travel Research, 48(1), 29-44. 
21. Jang, S., \& Feng, R. (2007). Temporal destination revisit intention: The effects of novelty seeking and satisfaction. Tourism Management, 28, 580-590.

22. Kandampully, J., Zhang, T., \& Bilgihan, A. (2015). Customer loyalty: A review and future directions with a special focus on the hospitality industry. International Journal of Contemporary Hospitality, 27(3), 379-414.

23. Kim, J. H. (2018). The Impact of Memorable Tourism Experiences on Loyalty Behaviors: The Mediating Effects of Destination Image and Satisfaction. Journal of Travel Research, 57(7), 856-870.

24. Kim, N. S., \& Chalip, L. (2004). Why travel to the FIFA World Cup? Effects of motives, background, interest, and constraints. Tourism Management, 25(6), 695-707.

25. Kim, S., Choe, J. Y., \& Petrick, J. (2018). The effect of celebrity on brand awareness, perceived quality, brand image, brand loyalty, and destination attachment to a literary festival. Journal of Destination Marketing \& Management, 9, 320-329.

26. Kozak, M. (2001). Repeaters' behavior at two distinct destinations. Annals of Tourism research, 28(3), 784-807.

27. Lončarić, D. (2015). Promocija u funkciji unaprjeđenja turizma hrvatskog dijela istarskog primorja - povijesni pregled. In: M. Šuligoj (ed.), Retrospektiva turizma Istre (pp. 327-358). Koper: University of Primorska Press.

28. Martínez González, J. A., Parra-Lopez, E., \& Buhalis, D. (2017). The loyalty of young residents in an island destination: An integrated model. Journal of Destination Marketing and Management, 6(4), 444-455.

29. Marušić, Z., Čorak, S., Sever, l., \& colleagues (2018). TOMAS ljeto - Stavovi i potrošnja turista u Hrvatskoj u 2017. godini. Zagreb: Institute for Tourism.

30. McGorry, S. (2000). Measurement in a cross-cultural environment: survey translation issues. Qualitative Market Research: An International Journal, 3(2), 74-81.

31. McKercher, B., \& Denizci Guillet, B. (2011). Are Tourist or Markets Destination Loyal?. Journal of Travel Research, 50(2), 121-132.

32. McKercher, B., Denizci-Guillet, B., \& Ng, E. (2012). Rethinking loyalty. Annals of Tourism Research, 39, 708-734.

33. McNaughton, R. B., Osborne, P., Morgan, R. E., \& Kutwaroo, G. (2001). A mediating and multigroup analysis of customer loyalty. Journal of Marketing Management, 17, 521-542.

34. Meleddu, M., \& Paci, R. P. (2015). Repeated behavior and destination loyalty. Tourism Management, 50, 159-171.

35. Mykletun, R. J., Crotts, J. C., \& Mykletun, A. (2001). Positioning an island destination in the peripheral area of the Baltics: A flexible approach to market segmentation. Tourism management, 22, 493-500.

36. Nunnally, J. (1978). Psychometric theory. New York, NY: McGraw-Hill.

37. Oliver, R. (1980). Cognitive model of the antecedents and consequences of satisfaction decisions. Journal of Marketing Research, 17, 46-49.

38. Oliver, R. (1999). Whence Consumer Loyalty?. Journal of Marketing, 63, 33-44.

39. Olsen, L. L., \& Johnson, M. D. (2003). Service Equity, Satisfaction, and Loyalty: From Transaction-Specific to Cumulative Evaluations. Journal of Service Research, 5(3), 184-195.

40. Oppermann, M. (1996). Visitation of tourism attractions and tourist expenditure patterns - repeat versus first- time visitors. Asia Pacific Journal of Tourism Research, 1(1), 61-68.

41. Palacios-Florencio, B., García del Junco, J., Castellanos-Verdugo, M., \& Rosa-Díaz, I. (2018). Trust as mediator of corporate social responsibility, image and loyalty in the hotel sector. Journal of Sustainable Tourism, 26(7), 1273-1289.

42. Pearce, P. (1982). The Social Psychology of Tourist Behavior. Pergamon: Oxford. 
43. Pedersen, P. E., \& Nysveen, H. (2001). Shopbot bank- ing: An exploratory study of customer loyalty effects. International Journal of Bank Management, 19(4), 146-155.

44. Petter, S., Straub, D., \& Rai, A. (2007). Specifying formative constructs in information systems research. MIS Quarterly, 31(4), 623-656.

45. Picon-Berjoyo, A., Ruiz-Moreno, C., \& Castro, I. (2016). A mediating and multigroup analysis of customer loyalty. European Management Journal, 34, 701-713.

46. Richards, G., \& Raymond, C. (2000). Creative tourism. ATLAS News, 23, 16-20.

47. Riley, M., Niininem, O., Szivas, E., \& Willis, T. (2001). The case for process approaches in loyalty research on tourism. International Journal of Tourism Research, 3, 23-32.

48. Rocco, M., \& Andrew, V. (2011). Hospitality today: An introduction. East Lansing, MI: Educational Institute of the American Hotel Motel Assoc.

49. Rodríguez Molina, M., Frías-Jamilena, D., \& Castañeda-García, J. (2013). he moderating role of past experience in the formation of a tourist destination's image and in tourists' behavioral intentions. Current Issues in Tourism, 16(2), 107-127.

50. Sato, S., Kim, H., Bunning, R., \& Harda, M. (2018). Adventure Tourism Motivation and Destination Loyalty: A Comparison of Decision and Non-Decision Makers. Journal of Destination Marketing and Management, 8, 74-81.

51. Stebbins, R. A. (1996). Volunteering: A Serious Leisure Perspective. Nonprofit and Voluntary Sector Quarterly, 25(2), 211-224.

52. Suhartanto, D., Brien, A., Primiana, I., Wibisono, N., \& Nyoman, T. (2019). Tourist loyalty in creative tourism: the role of experience quality, value, satisfaction, and motivation. Current Issues in Tourism, 23(7), 1-13.

53. Tasci, A. D. (2017). A quest for destination loyalty by profiling loyal travelers. Journal of Destination Marketing \& Management, 6(3), 207-220.

54. Vigolo, V. (2015). Investigating the Attractiveness of an Emerging Long-Haul Destination: Implications for Loyalty. International Journal of Tourism Research, 17(6), 564-576.

55. Wong, I., \& Tang, S. (2016). Linking Travel Motivation and Loyalty in Sporting Events: The Mediating Roles of Event Involvement and Experience, and the Moderating Role of Spectator Type. Journal of Travel \& Tourism Marketing, 33(1), 63-84.

56. Yolal, M., Chi, C., \& Pesämaa, O. (2017). Examine destination loyalty of first-time and repeat visitors at all-inclusive resorts. International Journal of Contemporary Hospitality Management, 29(7), 1834-1853.

57. Yoon, Y. U. (2005). An examination of the effects of motivation and satisfaction on destination loyalty: a structural model. Tourism Management, 26, 45-56.

58. Yuksel, A., Yuksel, F., \& Bilim, Y. (2010). Destination attachment: Effects on customer satisfaction and cognitive, affective and conative loyalty. Tourism Management, 31, 274-284. 